\title{
Merjenje napovednikov blagostanja med mladostniki v Sloveniji: psihometrične značilnosti mere MDI in dimenzij mere EPOCH
}

\author{
Ana Kozina ${ }^{1 *}$ in Valentina Čufar ${ }^{2}$ \\ ${ }^{1}$ Center za evalvacijske študije, Pedagoški inštitut
}

${ }^{2}$ Maribor

Povzetek: Merjenje blagostanja pridobiva pozornost tako na področju psiholoških raziskav, kot tudi na področju vzgoje in izobraževanja. V slovenskem prostoru lahko zaznamo pomanjkanje psihometrično veljavnih mer blagostanja pri otrocih in mladostnikih. V pričujoči raziskavi sva se osredotočili na psihometrične lastnosti dveh mer, ki merita dejavnike blagostanja za mladostnike: Merjenje razvoja otrok MDI (angl. Middle Years Development Inventory; Schonert-Reichl idr., 2013) in Mera blagostanja mladostnikov EPOCH (angl. Measure of Adolescent Well-Being; Kern, Benson, Steinberg in Steinberg, 2016). Za namene validacije obeh mer sva preverjali njuno strukturo, zanesljivost ter konvergentno in diskriminativno veljavnost. Analize so bile izvedene na podvzorcu PISA 2015. Vzorec zajema 3224 udeležencev s povprečno starostjo 16,65 let in standardnim odklonom 4,19. Konfirmatorna faktorska analiza je bila izvedena posebej za vprašalnik MDI in za dve dimenziji vprašalnika EPOCH. Rezultati konfirmatorne faktorske analize so pokazali zadovoljivo prilaganje modela izvorni različici v skladu s predpostavljeno strukturo. Vse dimenzije in podlestvice izbranih mer so zadovoljivo zanesljive (alfa koeficienti se gibljejo med 0,72 in 0,92). Analizirali sva koeficiente povezanosti med podlestvicami oziroma dimenzijami MDI in EPOCH ter dosežki na Vprašalniku spodbujanja pozitivnega razvoja mladih (PYD, Geldof idr., 2014) ter razlike med spoloma. Zaključiva lahko, da sta vprašalnika MDI in dve dimenziji vprašalnika EPOCH ustrezno zanesljivi in veljavni za uporabo v raziskovalne namene tudi v slovenskem prostoru.

Ključne besede: blagostanje, mladostniki, psihometrične značilnosti, veljavnost testa, pozitivna psihologija

\section{Well-being factors measurement in youth in Slovenia: psychometric properties of the measure MDI and two dimensions of the measure EPOCH}

\author{
Ana Kozina ${ }^{* *}$ and Valentina Čufar ${ }^{2}$ \\ 'Evaluation Studies Centre, Educational Research Institute, Slovenia \\ ${ }^{2}$ Maribor, Slovenia
}

\begin{abstract}
Well-being has gained importance in psychological research as well as in the field of education. However, there is a lack of validated questionnaires in Slovenia that would measure well-being in different domains in childhood and youth. In the present paper we focused on psychometric properties of two children and adolescent well-being measures: Middle Years Development Instrument (MDI; Schonert-Reichl et al., 2013) and Measure of Adolescent Well-Being (EPOCH; Kern, Benson, Steinberg, \& Steinberg, 2016). In order to validate the questionnaires, their structure, reliability and convergent and discriminant validity were analysed. Analyses were conducted on PISA 2015 subsample for Slovenia in an additional well-being study, with sample size 3224 (age: $M=16.65 ; S D=$ 4.19 years). Confirmatory factor analyses (CFA) were conducted separately for MDI and two dimensions of EPOCH. CFA indicated adequate fit for all expected models. Results showed satisfactory internal reliability of all subscales (alpha coefficients ranged from 0.72 to 0.92 ). Our research demonstrates evidence for convergent and discriminant validity (correlations between subscales, correlations with PYD questionnaire and with gender). The validation of presented measures speaks in favour of use of these questionnaires for studying factors of well-being in Slovenia.
\end{abstract}

Keywords: well-being, adolescents, psychometric properties, test validity, positive psychology

\footnotetext{
*Naslov/Address: Ana Kozina, Center za evalvacijske študije Pedagoški inštitut, Gerbičeva 62, 1000 Ljubljana, e-mail: ana.kozina@pei.si

Članek je licenciran pod pogoji Creative Commons Attribution 4.0 International licence. (CC-BY licenca).

The article is licensed under a Creative Commons Attribution 4.0 International License (CC-BY license).
} 
Blagostanje (angl. well-being) je v ospredju psiholoških raziskav, posebej na področju pozitivne psihologije, pridobiva pa tudi pomembno mesto na področju vzgoje in izobraževanja (OECD, 2017). Na področju vzgoje in izobraževanja blagostanje vstopa $\mathrm{v}$ ospredje tudi zaradi raziskav, ki poročajo o pomembni povezanosti blagostanja $\mathrm{z}$ učno uspešnostjo učencev in učenk ter dijakov in dijakinj (Antaramian, Huebner, Hills in Valois, 2010; Kozina in Štraus, 2017; Ng, Huebner in Hills, 2015). Učenke in učenci ter dijakinje in dijaki, ki poročajo o višjih ravneh blagostanja, izkazujejo višjo raven vključenosti v šolsko delo, tako znotraj razreda kot izven, se čutijo bolj pripadni šoli ter šoli namenijo več pozornosti (Antaramian idr., 2010). Za ugotavljanje pomembnih napovednikov blagostanja tako $\mathrm{v}$ tujini kot pri nas je $\mathrm{v}$ prvi vrsti potrebno zagotoviti psihometrično veljavno merjenje. V tujini obstaja kar nekaj mer blagostanja, medtem ko jih je manj v Sloveniji in hkrati so manjkrat predstavljene njihove merske značilnosti ( $\mathrm{z}$ izjemo magistrskih in doktorskih del).

Nekatere v literaturi uporabljene mere, namenjene merjenju blagostanja v obdobju otroštva in mladostništva, so: Indeks dobrega otroštva (The Good Childhood Index, The children's Society, 2017), ki meri zadovoljstvo z življenjem otrok z vprašanji z različnih področij: šola, videz, materialne dobrine, izbira, prihodnost, poraba časa, prijatelji, zdravje, družina, dom. Indeks osebnega blagostanja za šolske otroke (PWI SC - Personal Well-being Index - School Children; Cummins in Lau, 2005) je vprašalnik, namenjen šoloobveznim otrokom, in je sestavljen iz lestvic splošne sreče (HLW - Happiness with Life as a Whole) in osebnega blagostanja (PWI, Personal Wellbeing Index). Slednjo sestavljajo indikatorji: življenjski standard, osebno zdravje, dosežki, medosebni odnosi, osebna varnost, občutek pripadnosti skupnosti in varnost $\mathrm{V}$ prihodnosti (Cummins in Lau, 2005). Kidscreen-52 HRQOL je samoocenjevalni vprašalnik kvalitete življenja otrok in mladostnikov, starih med 8 in 18 let, sestavljen iz 10 dimenzij: telesno blagostanje, psihološko blagostanje, razpoloženje in čustva, samopodoba, avtonomija, odnosi z družino, socialna podpora in vrstniki, šolsko okolje, nadlegovanje ter finančni viri (Ravens-Sieberer idr., 2005). Podoben je tudi KINDL-R samoocenjevalni vprašalnik kvalitete življenja (KINDL-R questionnaire, Ravens-Sieberer in Bullinger, 1998) pri otrocih in mladostnikih, ki meri šest dimenzij: telesno blagostanje, čustveno blagostanje, samopodoba, družina, prijatelji in vsakodnevno delovanje v šoli ali vrtcu (Bullinger, Brütt, Erhart, Ravens-Sieberer in BELLA Study Group, 2008) in je dostopen tudi $\mathrm{v}$ srbskem jeziku (Stevanovic, 2009). Lestvica psihološkega blagostanja za otroke (PWB-c Psychological Well-Being scale for children; Opree, Buijzen, in Reijmersdal, 2018) je za otroke med 8 in 12 let prirejen Vprašalnik psihološkega blagostanja (PWB - Psychological Well-Being; Ryff, 1989), ki meri šest dimenzij: osebna rast, smisel življenja, sprejemanje sebe, avtonomija, pozitivni medosebni odnosi, obvladovanje okolja (Opree idr., 2018). V tujini je mer blagostanja res veliko, na primer Cooke, Melchert in Connor (2016) so identificirali kar 42 različnih mer.

V Sloveniji imamo nekaj prevodov tujih vprašalnikov, na primer Vprašalnik psihološkega blagostanja RPWB (Ryff's PWB; Ryff, 1989), ki vključuje šest dimenzij: osebna rast, smisel življenja, sprejemanje sebe, avtonomija, pozitivni medosebni odnosi in obvladovanje okolja. Na slovenskem vzorcu je validirana daljša in krajša oblika vprašalnika $s$ štirimi postavkami na dimenzijo. Zanesljivost krajše verzije se giblje med 0,56 in 0,77 , medtem ko ima daljša podobne značilnosti kot izvirna (Avsec in Sočan, 2009). Vprašalnik usmerjenosti k sreči (OTH; Peterson, Park in Seligman, 2005) meri tri različne načine doseganja sreče. To so užitek (hedonizem), smisel (eudaimonia) in zanos. Na slovenskem vzorcu so rezultati pokazali sprejemljivo prileganje modelu z zadovoljivo notranjo skladnostjo, Cronbachova alfa se na slovenskem vzorcu giblje med 0,70 in 0,83 (Avsec in Kavčič, 2012). Večina ostalih raziskav blagostanja na slovenskih vzorcih (Čufar, Kramaršek, Mahne in Mohar, 2015; Smolej Fritz in Avsec, 2007; Strniša, 2007) uporablja različne krajše vprašalnike za specifične pozitivne konstrukte: zadovoljstvo z življenjem (Lestvica zadovoljstva z življenjem - SWLS; Diener, Emmons, Larsen in Griffin, 1985), pozitivni in negativni afekt (Lestvica pozitivnega in negativnega afekta PANAS, Watson, Clark in Tellegen, 1988) in sreča (Oxfordov vprašalnik za merjenje sreče - OHQ, Hills in Argyle, 2002), s katerimi se meri subjektivno blagostanje ali hedonski model (Musek, 2015).

$\mathrm{V}$ prispevku izhajava iz potreb področja vzgoje in izobraževanja po ustreznih merskih pripomočkih za uporabo na populacijski ravni $\mathrm{v}$ obdobju šolanja, to je $\mathrm{v}$ obdobju srednjega in poznega otroštva ter mladostništva. V ospredju so tako mere, ki se v tovrstne namene uporabljajo v tujini. Ena od takih je mera, uporabljena v raziskavi Centra za izobraževanje in razvoj otrok v južni Avstraliji (Department for Education and Child Development in South Australia), to je mera MDI (Merjenje razvoja otrok; Middle Years Development Instrument; Schonert-Reichl idr., 2013). Uporabni sta tudi dve dimenziji mere EPOCH (Mera blagostanja mladostnikov, Measure of adolescent well-being; Kern idr., 2016). MDI je še posebej osnovan $\mathrm{z}$ namenom populacijskega spremljanja razvojnih dejavnikov otrok in mladostnikov.

MDI (Schonert-Reichl idr., 2013) je samoocenjevalni vprašalnik, ki meri razvoj šolskih otrok na več področjih. Razvojnopsihološko se vprašalnik osredotoča na razvojno obdobje srednjega otroštva. Teoretično je osnovan na socialnem in emocionalnem učenju (Greenberg idr., 2003), pozitivni psihologiji (Csikszentmihalyi in Seligman, 2000), teoriji rezilientnosti (Masten, 2001) ter perspektivi pozitivnega razvoja mladih (Lerner, 2007). V ozadju izhaja tudi iz ekoloških razvojnih teorij (Bronfenbrenner, 1979) ter pomena odnosa za razvoj posameznika (Ryan in Deci, 2000). Vprašalnik je bil razvit $\mathrm{z}$ namenom ugotavljanja socialnega in emocionalnega razvoja in blagostanja otrok ter dejavnikov, ki se z zdravjem in blagostanjem pomembno povezujejo. Avtorji so na podlagi pregleda literature (npr. Eccles, 1999) izluščili tista razvojna področja ter podporne dejavnike, ki pomembno vplivajo na razvoj in blagostanje otrok. Na ta način so prepoznali šest širših dimenzij: socialni in emocionalni razvoj, povezanost (z vrstniki, odraslimi v šoli, doma in v soseščini), šolske izkušnje, telesno zdravje in dobro počutje, konstruktivno uporabo časa po šoli ter učno uspešnost. Učna uspešnost kasneje ni bila vključena v vprašalnik, saj šole že zbirajo podatke o učni uspešnosti. $\mathrm{Na}$ področju socialnega in emocionalnega razvoja so avtorji kot pomembne prepoznali naslednje konstrukte, vključene 
v končno različico vprašalnika: optimizem, empatija, prosocialno vedenje, žalost, anksioznost, zadovoljstvo $\mathrm{z}$ življenjem in zadovoljstvo s samim seboj (samopodoba). Na področju povezanosti so iskali mere podpore in pripadnosti odraslim doma, v šoli in v soseski. V končni različici so uporabljene naslednje lestvice: povezanost $\mathrm{z}$ odraslimi doma, povezanost $\mathrm{z}$ odraslimi $\mathrm{v}$ šoli, povezanost $\mathrm{z}$ odraslimi $\mathrm{v}$ soseski, vrstniški odnosi, prijateljstvo. Na področju šolskih izkušenj so v končni različici uporabljene naslednje lestvice: učna samoučinkovitost, viktimizacija, šolska klima, cilji, pripadnost šoli. Na področju telesnega zdravja in dobrega počutja so avtorji poskušali vključiti opredelitve zdravja, pozitivno telesno samopodobo in zdrave življenjske navade. $\mathrm{V}$ končni različici so uporabljene posamezne postavke, ne lestvice. V konstruktivno porabo časa (po šoli) po mnenju avtorjev sodijo različne aktivnosti, kot je sodelovanje $\mathrm{v}$ obšolskih dejavnostih in aktivnostih, prostovoljstvo, razni krožki (npr. športni), gledanje televizije, igranje računalniških iger. V končni različici so uporabljene posamezne postavke, ne lestvice.

Na tej osnovi so Schonert-Reichl idr. (2013) v procesu razvoja merskega pripomočka analizirali merske pripomočke, ki bi identificirane konstrukte znotraj prepoznanih področij psihometrično ustrezno merili. Pri izbiri mer izbranih kontruktov so se naslonili na visoko zanesljivost (nad 0,70 ), dokaze diskriminativne, konvergentne in vsebinske veljavnosti ter razvojno ustreznost. $\mathrm{V}$ začetni različici je vprašalnik vključeval preko 300 postavk iz preko 100 merskih pripomočkov. Zaradi uporabe na ravni populacije je bilo dodatno vodilo tudi manjše število postavk na merjen konstrukt, pri tem so se avtorji omejili na tri do pet postavk na mersko lestvico. Vprašalnik je vključeval več različic in več nadgradenj tudi $\mathrm{z}$ vključevanjem povratnih informacij različnih skupin (fokusne skupine z raziskovalci, otroki, učitelji, starši, politiki).

Dodatno sva, poleg preverjanja psihometričnih značilnosti vprašalnika MDI, v preverjanje psihometričnih značilnosti vključili tudi dve dimenziji vprašalnika EPOCH, ki sta se izkazali kot pomembna napovednika učne uspešnosti v šolskem okolju, zavzetost in vztrajnost (Kern idr., 2016). EPOCH sicer meri pet napovednikov blagostanja, izhaja iz Seligmanovega PERMA modela (Seligman, 2011) in je namenjen uporabi v obdobju mladostništva. Podobno kot MDI se tudi ta opira na perspektivo pozitivnega razvoja mladih (Lerner idr., 2009). EPOCH meri naslednje napovednike blagostanja: zavzetost (angl. engagement), vztrajnost (angl. perseverance), optimizem (angl. optimism), povezanost (angl. connectedness) in sreča (angl. happiness). Zavzetost je opredeljena kot sposobnost osredotočenosti na to, kar nekdo počne, kot tudi interes in vključenost $\mathrm{v}$ aktivnosti in naloge v življenju. Navezovala se bi naj na zanos (angl. flow), ki ga je opredelil Csikszentmihalyi (1997). Vztrajnost se nanaša na sposobnost zasledovanja svojih ciljev, kljub morebitnim oviram. Naj bi se povezovala z vestnostjo, enim izmed velikih petih faktorjev osebnosti.

$\mathrm{Za}$ namene preverjanja veljavnosti obeh vključenih mer sva uporabili tudi Vprašalnik spodbujanja pozitivnega razvoja mladih PYD (Positive Youth Development, Geldof idr., 2014). Vprašalnik je bil izbran zaradi podobnih teoretičnih ozadij. Podobno kot MDI tudi vprašalnik PYD izhaja iz perspektive pozitivnega razvoja mladih (Lerner, 2007), ekoloških razvojnih teorij (Bronfenbrenner, 1979) ter teorije samodeterminacije (Ryan in Deci, 2000). Hkrati je namenjen uporabi v obdobju mladostništva, kar MDI ni, in je informacija o povezavah informativna tudi za uporabo MDI na vzorcih mladostnikov. Vprašalnik vključuje pet dimenzij: kompetentnost (angl. competence), samozavest (angl. confidence), karakter (angl. character), skrb (angl. caring) in povezanost (angl. connection). Dimenzija kompetentnost je opredeljena kot pozitiven pogled na svoje aktivnosti in sposobnosti, nanaša se na specifična področja (socialno, učno, spoznavno in poklicno). Samozavest se nanaša na notranji občutek lastne vrednosti in samoučinkovitosti. Dimenzija karakter je definirana kot spoštovanje societalnih in kulturnih pravil, posedovanje standardov korektnega vedenja, moralnost in integriteta. Dimenzija skrb je definirana kot sposobnost simpatije in empatije do drugih. Dimenzija povezanost se nanaša na pozitivne odnose $\mathrm{z}$ ljudmi in institucijami (vrstniki, družino, šolo, soseščino, skupnostjo) (Geldof idr., 2014; Phelps idr., 2009;). Struktura vprašalnika je bila potrjena tudi na slovenski različici (Kozina, Wiium, Gonzales in Dimitrova, 2018).

\section{Problem in cilji raziskave}

V Sloveniji je $\mathrm{v}$ tem trenutku malo mer napovednikov blagostanja otrok in mladostnikov, ki bi bile prenesene $\mathrm{v}$ slovenski prostor ter psihometrično preverjene, zato se $\mathrm{v}$ prispevku osredinjava na veljavnost in zanesljivost dveh izbranih in $\mathrm{v}$ tujini uveljavljenih mer napovednikov blagostanja. Sledili bova naslednjim raziskovalnim vprašanjem in hipotezam:

1) Kakšna je zanesljivost in veljavnost slovenskega prevoda vprašalnika MDI? Predpostavljava visoko zanesljivost ter skladnost strukture vprašalnika $\mathrm{z}$ izvirno različico.

2) Kakšna je zanesljivost in veljavnost slovenskega prevoda dveh dimenzij (zavzetost in vztrajnost) vprašalnika EPOCH? Predpostavljava visoko zanesljivost ter skladnost strukture vprašalnika z izvirno različico.

3) Kakšna je konvergentna in diskriminantna veljavnost vprašalnika MDI ter dveh dimenzij vprašalnika EPOCH? Preverili bova povezovanje $\mathrm{z}$ dimenzijami vprašalnika PYD. Glede na predhodne raziskave (Schonert-Reichl idr., 2013) vprašalnika MDI predpostavljava: (i) pozitivno povezanost med MDI podlestvicami optimizem, zadovoljstvo s samim seboj in zadovoljstvo z življenjem; (ii) pozitivno povezanost med žalostjo in anksioznostjo; (iii) pozitivno povezanost med empatijo in prosocialnim vedenjem; (iv) pozitivno povezanost med odnosi z vrstniki in prijateljstvom; (v) pozitivno povezanost med odnosi z odraslimi doma, odnosi z odraslimi v šoli, odnosi z odraslimi v soseski; (vi) pozitivno povezanost med učno samoučinkovitostjo, šolsko klimo ter pripadnostjo šoli ter negativno $\mathrm{z}$ viktimizacijo. Znotraj obeh dimenzij EPOCH (vztrajnost in zavzetost) v skladu s predhodnimi raziskavami (Kern idr., 2016) predpostavljava njuno pozitivno povezanost. Predpostavljava tudi visoko povezanost med vsebinsko sorodnimi konstrukti različnih mer, na primer: (i) povezanostjo, merjeno $\mathrm{z}$ MDI, in 
povezanostjo, merjeno s PYD; (ii) empatijo, merjeno $\mathrm{z}$ MDI, ter skrbjo, merjeno s PYD.

4) Dodatno so naju zanimale tudi razlike med spoloma $\mathrm{v}$ dosežkih na dimenzijah MDI in EPOCH ter merska invariatnost po spolu.

\section{Metoda}

\section{Udeleženci}

$\mathrm{V}$ raziskavi je sodelovalo 3224 dijakinj in dijakov, $\mathrm{v}$ povprečju starih 16 let $(M=16,65, S D=4,19)$. Od tega je bilo $63,1 \%$ starih 16 let in $29,7 \%$ starih 17 let. V vzorec je bilo vključenih 50,8 \% deklet in 49,1\% fantov. Gre za del vzorca raziskave PISA 2015 (Programme for International Students Assessment). Dijakinje in dijaki, ki so bili vključeni v raziskavo PISA 2015 (6406 dijakov, od tega 2901 deklet in 3505 fantov, s povprečno starostjo 15,7 let), so bili leto kasneje povabljeni $\mathrm{v}$ raziskavo dejavnikov blagostanja. Osnovne primerjave dosežkov podvzorca raziskave dejavnikov blagostanja s celotnim vzorcem PISA 2015 v Sloveniji so pokazale, da je podvzorec raziskave dejavnikov blagostanja na testih pismenosti PISA 2015 dosegel nekoliko višje vrednosti (520 proti 505 točk v branju, 520 proti 510 točk v matematiki in 527 proti 513 točkam v naravoslovju). Prav tako je podvzorec raziskave blagostanja poročal o višjih vrednostih nekaterih ozadenjskih spremenljivk, na primer socialno-ekonomskem in kulturnem statusu. Analize drugih značilnosti vzorca niso odkrile pomembnih razlik med vzorcem PISA 2015 in vzorcem raziskave dejavnikov blagostanja. Ugotavljava, da vzorec raziskave blagostanja predstavlja nekoliko zamaknjeno distribucijo po pismenosti, je boljši predstavnik visokih ravni pismenosti v primerjavi z nižjimi ravnmi pismenosti.

\section{Pripomočki}

Merjenje razvoja otrok MDI. Vprašalnik MDI (Middle Years Development Instrument; Schonert-Reichl idr., 2013) meri napovednike otrokovega blagostanja $\mathrm{v}$ okviru šole in izven nje. Namenjen je otrokom, starim med 6 in 12 let. $\mathrm{V}$ raziskavi sva preverjali njegovo uporabo na vzorcu mladostnikov. Sestavlja ga pet sklopov napovednikov na petstopenjski lestvici ( 1 - se popolnoma ne strinjam, 5 - se popolnoma strinjam): (1) socialni in emocionalni razvoj (optimizem - 3 postavke; zadovoljstvo z življenjem - 5 postavk; zadovoljstvo s samim seboj - 3 postavke; empatija - 3 postavke; žalost/skrbi - 6 postavk; prosocialno vedenje - 3 postavke), (2) povezanost (povezanost $\mathrm{z}$ vrstniki - 3 postavke, povezanost $\mathrm{z}$ odraslimi $\mathrm{v}$ šoli -3 postavke, povezanost $\mathrm{z}$ odraslimi doma -3 postavke in povezanost $\mathrm{z}$ odraslimi v soseščini -3 postavke, prijateljstvo -3 postavke (3) šolske izkušnje (učna samoučinkovitost - 3 postavke; cilji - 1 postavka, pripadnost šoli - 2 postavki, šolska klima -3 postavke, viktimizacija - 4 postavke), (4) telesno zdravje in dobro počutje (splošno zdravje - 1 postavka; oviranost - 1 postavka; telesna samopodoba -1 postavka, prehrana in spanje - 1 postavka) ter (5) konstruktivna poraba časa po šoli. Vprašalnik MDI je $\mathrm{v}$ angleškem jeziku prosto dostopen za nekomercialne namene, slovenski prevod je na voljo pri avtoricah.
Mera napovednikov blagostanja pri mladostnikih ЕРОСН (Mesure of Adolescent Well-Being; Kern idr., 2016) je namenjena merjenju napovednikov blagostanja, dobrega počutja, telesnega zdravja in ostalih pozitivnih izidov pri mladostnikih. Meri pet dimenzij: (1) zavzetost, (2) vztrajnost, (3) optimizem, (4) povezanost in (5) sreča. Sestavljen je iz 20 postavk na petstopenjski odgovorni lestvici (1 - skoraj nikoli/sploh ni značilno zame, 5 - skoraj vedno/ popolnoma je značilno zame). V preverjanje psihometričnih značilnosti sta bili vključeni dve dimenziji vprašalnika, to sta zavzetost in vztrajnost. Ti dve dimenziji sta bili izbrani kot komplementarni dimenzijam vprašalnika MDI z namenom, da skupaj tvorijo širok nabor napovednikov blagostanja mladostnikov. Vprašalnik EPOCH je $\mathrm{v}$ angleškem jeziku prosto dostopen za nekomercialne namene, slovenski prevod obeh analiziranih dimenzij je na voljo pri avtoricah.

Vprašalnik spodbujanja pozitivnega razvoja mladih PYD (Positive Youth Development, Geldof idr., 2014) je sestavljen iz 34 postavk in meri pozitivni razvoj mladih $\mathrm{z}$ uporabo petstopenjske odgovorne lestvice (1 - se popolnoma ne strinjam, 5 - popolnoma se strinjam). Meri pet dimenzij (ang. 5Cs): kompetentnost (npr. »Pri šolskem delu sem uspešna oziroma uspešen«), zaupanje (npr. »Večino časa sem zadovoljna sama s sabo oziroma zadovoljen sam s sabo.«), skrb (npr. »Ko vidim koga, ki trpi ali mu je težko, se mi smili.«), karakter (npr. »Skoraj nikoli ne naredim kaj, kar ne bi smela oziroma smel.«) in povezanost (npr. »Moji prijatelji skrbijo zame«). Vprašalnik ima tudi na slovenskem vzorcu dobre psihometrične lastnosti s koeficienti zanesljivosti: 0,78 (kompetentnost); 0,82 (samozavest); 0,74 (karakter); 0,91 (skrb); 0,81 (povezanost). Konfirmatorna faktorska analiza je pokazala dobro ujemanje s petfaktorsko strukturo (Kozina, Wiium, Gonzales in Dimitrova, 2018).

\section{Postopek}

Šole, ki so sodelovale v raziskavi PISA 2015, so bile povabjene k sodelovanju v raziskavi o dejavnikih blagostanja leto po zajemu PISA podatkov. Program mednarodne primerjave dosežkov učencev PISA je mednarodna raziskava primerjanja kompetenc učenk in učencev v državah članicah Organizacije za ekonomsko sodelovanje in razvoj (OECD) in državah partnericah. Raziskava je bila v mednarodnem prostoru prvič izvedena leta 2000 in od takrat države na tri leta ugotavljajo ravni bralne, matematične in naravoslovne pismenosti dijakinj in dijakov v starosti 15 let. Šole, ki so se odločile za sodelovanje, so pridobile informirano soglasje skrbnikov za sodelovanje dijakinj in dijakov $\mathrm{v}$ raziskavi. Dijakinje in dijake, ki so sprejeli sodelovanje, so odgovorili na postavke MDI, EPOCH in PYD v e-obliki v okviru pouka in pod nadzorom koordinatorja raziskave na šoli. Reševanje ni bilo časovno omejeno in v povprečju ni presegalo 45 minut.

\section{Statistične analize}

Za statistične analize sva uporabljali program IBM SPSS 21. Najprej sva izračunali opisne statistike. Za preverjanje strukture vprašalnika sva s programom Amos graphics 21 izvedli konfirmatorno faktorsko analizo. Strukturo vsakega vprašalnika sva preverjali posebej. Pri vprašalniku MDI 
Tabela 1. Faktorska struktura dimenzij vprašalnika MDI

\begin{tabular}{|c|c|c|c|c|c|c|c|c|c|}
\hline \multirow{2}{*}{\multicolumn{2}{|c|}{$\begin{array}{l}\text { Model } \\
\text { MDI - Socialni in emocionalni razvoj }\end{array}$}} & MSEA [90 \% IZ] & \multirow[t]{2}{*}{ SRMR } & \multirow[t]{2}{*}{ NFI } & \multirow[t]{2}{*}{ TLI } & \multirow[t]{2}{*}{ CFI } & \multirow[t]{2}{*}{$\chi^{2}$} & \multirow[t]{2}{*}{$d f$} & \multirow[t]{2}{*}{$p$} \\
\hline & & & & & & & & & \\
\hline Model 1 & 0,14 & {$[0,14 ; 0,15]$} & 0,12 & 0,56 & 0,51 & 0,56 & 15525,72 & 230 & $<0,001$ \\
\hline Model 2 & 0,10 & {$[0,10 ; 0,11]$} & 0,23 & 0,77 & 0,75 & 0,77 & 8182,634 & 230 & $<0,001$ \\
\hline Model 3 & 0,05 & {$[0,05 ; 0,05]$} & 0,04 & 0,95 & 0,95 & 0,96 & 1710,114 & 208 & $<0,001$ \\
\hline Model 4 & 0,07 & {$[0,07 ; 0,07]$} & 0,07 & 0,90 & 0,89 & 0,91 & 3484,01 & 224 & $<0,001$ \\
\hline \multicolumn{10}{|c|}{ MDI - Povezanost } \\
\hline Model 1 & 0,24 & {$[0,24 ; 0,24]$} & 0,19 & 0,40 & 0,30 & 0,40 & 16862,86 & 90 & $<0,001$ \\
\hline Model 2 & 0,10 & {$[0,09 ; 0,10]$} & 0,20 & 0,90 & 0,89 & 0,91 & 2696,68 & 90 & $<0,001$ \\
\hline Model 3 & 0,04 & {$[0,04 ; 0,04]$} & 0,03 & 0,98 & 0,98 & 0,99 & 499,84 & 80 & $<0,001$ \\
\hline Model 4 & 0,05 & {$[0,04 ; 0,05]$} & 0,05 & 0,97 & 0,97 & 0,98 & 706,70 & 85 & $<0,001$ \\
\hline \multicolumn{10}{|c|}{ MDI - Šolske izkušnje } \\
\hline Model 1 & 0,21 & {$[0,21 ; 0,22]$} & 0,16 & 0,41 & 0,25 & 0,41 & 5269,45 & 35 & $<0,001$ \\
\hline Model 2 & 0,07 & {$[0,07 ; 0,08]$} & 0,10 & 0,93 & 0,91 & 0,93 & 632,26 & 35 & $<0,001$ \\
\hline Model 3 & 0,05 & {$[0,05 ; 0,06]$} & 0,03 & 0,97 & 0,96 & 0,97 & 298,54 & 32 & $<0,001$ \\
\hline Model 4 & 0,05 & {$[0,05 ; 0,06]$} & 0,03 & 0,97 & 0,96 & 0,97 & 298,54 & 32 & $<0,001$ \\
\hline
\end{tabular}

Opombe. Model 1 = enofaktorski; Model 2 = nekoreliran; Model $3=$ koreliran; Model 4 = model višjega reda. Vrednosti znotraj oglatih oklepajev pri RMSEA predstavljajo meje 90-odstotnega intervala zaupanja [spodnja meja, zgornja meja].

se je ujemanje modela preverjalo za vsako izmed dimenzij napovednikov blagostanja posebej (socialni in emocionalni razvoj, povezanost in šolske izkušnje), skladno z analizami prvotne študije. Strukture dimenzije zdravje nisva preverjali s pomočjo konfirmatorne faktorske analize, saj postavke niso sestavljene iz lestvic, temveč zgolj iz posameznih kategoričnih postavk (nestandardiziranih odgovornih lestvic), pričemer ista vrednost na različnih postavkah predstavlja drugačno vsebino odgovora. Tako odgovorne lestvice niso standardizirane in ne omogočajo primerjave. Skladno z analizami prvotne študije, sva se tudi midve za potrjevanje modela osredotočili predvsem na korelacije postavke splošnega zdravja $\mathrm{z}$ ostalimi postavkami iz dimenzije (Schonert-Reichl idr., 2013). Tudi za EPOCH sva, podobno kot $\mathrm{v}$ raziskavi Kern in sodelavci (2016), pri vsakem preverili skladnosti osnovnega modela, to je modela, kjer sva upoštevali korelacije med dimenzijami, enofaktorskega modela in modela višjega reda. Vse spremenljivke sva obravnavali kot zvezne. Vse so se tudi porazdeljevale približno normalno, na podlagi česar sva parametre ocenili z metodo največjega verjetja (ML, angl. maximum likelihood). Ujemanje modela sva zaradi velikega vzorca preverjali z RMSEA (Root Mean Square Error of Approximation)in SRMR(Standardized RootMean Residual), ki sta meri, na kateri ima velikost vzorca najmanj vpliva. Dodatno sva ujemanje preverjali tudi z indeksi NFI (Normed Fit Index), TLI (Tucker Lewis Index), CFI (Comparative Fit Index) ter $\mathrm{s} \chi^{2}$ testom. Pri ugotavljanju skladnosti modelov sva upoštevali naslednje pogoje: (a) CFI $>0,95$, (b) TLI $>0,95$, (c) SRMR $<0,08$ in (d) RMSEA $<0,08$ (Brown, 2006). Na vseh dimenzijah sva preverili tudi mersko invariantnost po spolu (konfiguralno, metrično, skalarno in strogo). Zaradi velikega vzorca sva za potrjevanje invariantnosti vzeli pogoj $\Delta$ CFI < 0,01 (Byrne, 2010). Za preverjanje zanesljivosti sva izračunali McDonaldov omega $(\omega)$ in alfa koeficiente zanesljivosti (Cronbachov $\alpha$ ). McDonaldov omega sva izračunali $\mathrm{s}$ pomočjo programa JASP 0.9.2.0. Vse vrednosti dimenzij obeh vprašalnikov so bile nato izračunane kot seštevek vrednosti na postavkah, vezanih na določeno dimenzijo. Konstruktno veljavnost (diskriminativno in konvergentno) sva preverjali z izračunom Pearsonovih koeficientov korelacije. Na dimenziji zdravje vprašalnika MDI sva zaradi kategoričnih postavk povezanosti izračunali s pomočjo Spearmanovega koeficienta korelacije. Primerjavo po spolu sva izvedli z MANOVO. Za kriterij statistične značilnosti sva vzeli 5-odstotno verjetnost alfa napake.

\section{Rezultati z razpravo}

\section{Vprašalnik MDI}

S konfirmatorno faktorsko analizo sva preverjali ujemanje slovenskega prevoda vprašalnika MDI s strukturovprašalnika, predvideno v raziskavi Schonert-Reichla idr. (2013). Preverjali sva tako modele, kjer je dopuščena vzajemna povezanost (model 3) med podlestvicami (latentnimi spremenljivkami), kot modele brez vključitve vzajemne povezanosti (model 2). V tabeli 1 so prikazani rezultati prileganja modelov podatkom. Prileganje sva preverjali z različnimi merami (CFI, TLI, SRMR in RMSEA).

Iz tabele 1 je razvidno, da kaže model 3 (model, kjer je upoštevana povezanost med podlestvicami), za dimenziji socialni in emocionalni razvoj in povezanost, boljše prileganje podatkom kot model 2 (brez medsebojne povezanosti med podlestvicami), model 1 (enofaktorski model) in model 4 (model višjega reda). Vse mere kažejo dobro prileganje $(\mathrm{CFI}>0,95, \mathrm{TLI}>0,95$, SRMR $<0,08$ in RMSEA $<0,08)$. Preverjali sva tudi mersko invariantnost po spolu. Iz tabele 2 je razvidno, da sta dimenziji emocionalni in socialni razvoj ter povezanost vsaj skalarno, če ne tudi strogo mersko invariantni po spolu, saj je sprememba indeksa CFI za vse modele manjša od 0,01 . Indeksi prileganja kažejo dobro prileganje vseh modelov podatkom (od konfiguralnega do strogega). Nekoliko višja sprememba v indeksih prileganja se pojavi pri strogi invariantnosti (glej spremembo indeksa od skalarnega do strogega modela), vendar je ta še vedno sprejemljiva. 
Tabela 2. Primerjava modelov za preverjanje merske invariantnosti glede na spol za vprašalnik MDI

\begin{tabular}{lrrrr}
\hline Model & \multicolumn{1}{c}{$\Delta \chi^{2}$} & $\Delta d f$ & \multicolumn{1}{c}{$p$} & \multicolumn{1}{c}{$\Delta$ CFI } \\
\hline \multicolumn{2}{l}{ Emocionalni in socialni razvoj } & & & \\
Metrični : konfiguralni & 42,66 & 16 & $<0,01$ & $<0,001$ \\
Skalarni : metrični & 187,51 & 28 & $<0,01$ & 0,005 \\
$\quad$ Strogi : skalarni & 165,47 & 23 & $<0,01$ & 0,004 \\
Povezanost & & & & \\
Metrični : konfiguralni & 41,06 & 10 & $<0,01$ & 0,001 \\
Skalarni : metrični & 56,32 & 15 & $<0,01$ & 0,002 \\
Strogi : skalarni & 200,21 & 15 & $<0,01$ & 0,006 \\
Šolske izkušnje & & & & \\
$\quad$ Metrični : konfiguralni & 206,31 & 7 & $<0,01$ & 0,022 \\
$\quad$ Skalarni : metrični & 127,20 & 6 & $<0,01$ & 0,014 \\
Šolske izkušnje brez viktimizacije & & & \\
$\quad$ Metrični : konfiguralni & 15,23 & 4 & 0,004 & 0,001 \\
$\quad$ Skalarni : metrični & 7,21 & 3 & 0,065 & 0,001 \\
Strogi : skalarni & 94,10 & 6 & $<0,01$ & 0,010 \\
\hline
\end{tabular}

Šolske izkušnje sestavlja šest podlestvic, vendar sva zaradi prekratkih mer (npr. mera ciljev $\mathrm{z}$ eno postavko) $\mathrm{v}$ konfirmatorno faktorsko analizo vključili le podlestvice učna samoučinkovitost, šolska klima in viktimizacija, kar je v skladu z analizami Schonert-Reichla in sodelavcev (2013). Iz tabele 1 je razvidno, da kaže model 3 (model, kjer je upoštevana povezanost med podlestvicami) boljše prileganje podatkom kot model 2 (brez medsebojne povezanosti med podlestvicami) in model 1 (enofaktorski model). Model 4 (model višjega reda) kaže enako ujemanje kot model 3, vendar bova zaradi skladnosti s teorijo uporabljali model 3. Vse mere kažejo zelo dobro prileganje (CFI > 0,95, TLI > 0,95, SRMR $<0,08$ in RMSEA $<0,08$ ) in tako potrjujejo predvideno strukturo. Preverjali sva tudi mersko invariantnost po spolu za dimenzijo šolske izkušnje. Iz tabel 2 in 3 je razvidno, da $\mathrm{z}$ običajno dimenzionalnostjo nisva mogli potrditi niti metrične invariantnosti, saj je bila razlika v indeksu CFI med konfiguralnim in metričnim modelom večja od 0,01 . Po pregledu modifikacijskih indeksov sva ugotovili, da se model prilega podatkom, če ne izenačiva nasičenosti na postavkah iz podlestvice viktimizacija. Tako sva naredili ponovno analizo brez omenjene podlestvice. Rezultati kažejo, da je dimenzija šolske izkušnje brez podlestvice viktimizacija skalarno invariantna (razlika v indeksu CFI med metričnim in skalarnim modelom je manjša od 0,01 ). To pomeni, da dečki in deklice različno razumejo in odgovarjajo na postavke podlestvice viktimizacije. $\mathrm{Na}$ tem mestu bodo potrebne nadaljnje raziskave veljavnosti podlestvice viktimizacije, preden jo bova lahko priporočili za nadaljnjo uporabo.

Dimenzija zdravje sestoji iz posamičnih kategoričnih postavk z različnimi vsebinami odgovorov, zaradi česar podatkov ni bilo mogoče analizirati s konfirmatorno faktorsko analizo. V tabeli 4 so tako prikazane postavke, s katerimi je bilo zdravje merjeno, odgovorni format, razpon odgovorov, njihovo povprečje in standardni odklon. Potrjevanje konstrukta je tako možno le preko korelacij postavk s postavko splošne ocene zdravja, čemur se bova podrobneje posvetili v nadaljevanju.

Nadalje sva preverjali tudi zanesljivost naslednjih dimenzij MDI vprašalnika: socialni in emocionalni razvoj, šolske izkušnje in povezanost. Rezultati vseh koeficientov notranje skladnosti na vseh podlestvicah vprašalnika MDI kažejo za uporabo $v$ raziskovalne namene še sprejemljivo zanesljivost $(\alpha>0,7$ in $\omega>0,70)$, za dimenzijo socialni in emocionalni razvoj se gibljejo $v$ razponu med 0,72 in 0,89 (tabela 5); za dimenzijo povezanost se gibljejo $\mathrm{v}$ razponu med 0,82 in 0,93 (tabela 6); ter za dimenzijo šolske izkušnje med 0,77 in 0,75 (tabela 7). Hkrati pa se rezultati skladajo z zanesljivostjo, izmerjeno $\mathrm{v}$ predhodni raziskavi, nekateri koeficienti pa

Tabela 3. Indeksi prileganja modelov merske invariantnosti glede na spol za vprašalnik MDI

\begin{tabular}{|c|c|c|c|c|c|c|c|}
\hline \multirow{2}{*}{$\begin{array}{l}\text { Model } \\
\text { Emocionalni in socialni razvoj }\end{array}$} & \multicolumn{2}{|c|}{ RMSEA [90 \% IZ] } & \multirow[t]{2}{*}{ NFI } & \multirow[t]{2}{*}{ TLI } & \multirow[t]{2}{*}{ CFI } & \multirow[t]{2}{*}{$\chi^{2} / d f$} & \multirow[t]{2}{*}{$p$} \\
\hline & & & & & & & \\
\hline Konfiguralni & 0,03 & {$[0,03 ; 0,04]$} & 0,95 & 0,95 & 0,96 & 4,53 & $<0,01$ \\
\hline Metrični & 0,03 & {$[0,03 ; 0,03]$} & 0,94 & 0,95 & 0,96 & 4,46 & $<0,01$ \\
\hline Skalarni & 0,03 & {$[0,03 ; 0,04]$} & 0,94 & 0,95 & 0,95 & 4,60 & $<0,01$ \\
\hline Strogi & 0,03 & {$[0,03 ; 0,04]$} & 0,93 & 0,94 & 0,95 & 4,72 & $<0,01$ \\
\hline Povezanost & & & & & & & $<0,01$ \\
\hline Konfiguralni & 0,03 & {$[0,03 ; 0,03]$} & 0,98 & 0,98 & 0,98 & 3,82 & $<0,01$ \\
\hline Metrični & 0,03 & {$[0,03 ; 0,03]$} & 0,98 & 0,98 & 0,98 & 3,84 & $<0,01$ \\
\hline Skalarni & 0,03 & {$[0,03 ; 0,03]$} & 0,98 & 0,98 & 0,98 & 3,83 & $<0,01$ \\
\hline Strogi & 0,03 & {$[0,03 ; 0,04]$} & 0,97 & 0,97 & 0,98 & 4,54 & $<0,01$ \\
\hline Šolske izkušnje & & & & & & & $<0,01$ \\
\hline Konfiguralni & 0,04 & {$[0,03 ; 0,04]$} & 0,97 & 0,96 & 0,97 & 4,85 & $<0,01$ \\
\hline Metrični & 0,04 & {$[0,04 ; 0,05]$} & 0,94 & 0,94 & 0,95 & 7,28 & $<0,01$ \\
\hline Skalarni & 0,05 & {$[0,04 ; 0,05]$} & 0,93 & 0,93 & 0,94 & 8,36 & $<0,01$ \\
\hline \multicolumn{8}{|c|}{ Šolske izkušnje brez viktimizacije } \\
\hline Konfiguralni & 0,04 & {$[0,03 ; 0,04]$} & 0,97 & 0,96 & 0,97 & 4,85 & $<0,01$ \\
\hline Metrični & 0,03 & {$[0,03 ; 0,04]$} & 0,96 & 0,96 & 0,97 & 4,79 & $<0,01$ \\
\hline Skalarni & 0,03 & {$[0,03 ; 0,04]$} & 0,96 & 0,96 & 0,97 & 4,69 & $<0,01$ \\
\hline Strogi & 0,04 & {$[0,03 ; 0,04]$} & 0,95 & 0,96 & 0,96 & 5,55 & $<0,01$ \\
\hline
\end{tabular}


Tabela 4. Prikaz odgovornih lestvic in opisnih statistike za lestvico zdravje

\begin{tabular}{|c|c|c|c|}
\hline MDI: zdravje & Odgovorna lestvica & $M$ & $S D$ \\
\hline \multicolumn{4}{|l|}{ Splošno zdravje } \\
\hline R066 - splošna ocena zdravja & $1=$ zelo podpovprečno do $5=$ zelo nadpovprečno & 3,08 & 0,78 \\
\hline \multicolumn{4}{|l|}{ Spanje in prehranjevanje } \\
\hline R070 -zajtrkovanje & $1=$ nikoli do $8=$ sedemkrat tedensko & 4,76 & 2,74 \\
\hline R071 -prehranjevanje z družino & $1=$ nikoli do $8=$ sedemkrat tedensko & 5,54 & 2,26 \\
\hline R072 - nezdrave prehranjevalne navade & $1=$ nikoli do $8=$ sedemkrat tedensko & 3,95 & 2,00 \\
\hline R074 -spanje & $1=$ pred deveto do $5=$ po polnoči & 3,33 & 0,95 \\
\hline \multicolumn{4}{|l|}{ Telesna podoba } \\
\hline R068 - telesna teža & $1=$ zelo podpovprečno do $5=$ zelo nadpovprečno & 3,08 & 0,78 \\
\hline R069 - zadovoljstvo z videzom (pogostost) & $1=$ nikoli do $5=$ vedno & 3,36 & 0,94 \\
\hline
\end{tabular}

Tabela 5. Zanesljivost dimenzije vprašalnika MDI: socialni in emocionalni razvoj

\begin{tabular}{|c|c|c|c|c|c|c|}
\hline MDI: socialni in emocionalni razvoj & Nasičenost & $M$ & $S D$ & $\alpha$ & $\alpha(p)$ & $\omega$ \\
\hline Empatija & & 12,08 & 2,29 & 0,72 & 0,65 & 0,73 \\
\hline R041 & 0,57 & 3,80 & 1,04 & & & \\
\hline R042 & 0,75 & 4,31 & 0,88 & & & \\
\hline R043 & 0,73 & 3,97 & 0,94 & & & \\
\hline Prosocialno vedenje & & 7,81 & 3,02 & 0,78 & 0,82 & 0,80 \\
\hline R056 & 0,62 & 3,34 & 2,22 & & & \\
\hline R057 & 0,91 & 2,34 & 1,23 & & & \\
\hline R058 & 0,72 & 2,13 & 1,17 & & & \\
\hline Žalost & & 7,96 & 2,54 & 0,76 & 0,70 & 0,77 \\
\hline R044 & 0,79 & 2,22 & 1,02 & & & \\
\hline R045 & 0,62 & 2,96 & 1,00 & & & \\
\hline R046 & 0,76 & 2,78 & 1,05 & & & \\
\hline Skrbi & & 8,30 & 3,43 & 0,89 & 0,80 & 0,90 \\
\hline R047 & 0,87 & 2,90 & 1,27 & & & \\
\hline R048 & 0,92 & 2,78 & 1,25 & & & \\
\hline R049 & 0,80 & 2,62 & 1,26 & & & \\
\hline Optimizem & & 10,53 & 2,47 & 0,75 & 0,66 & 0,75 \\
\hline R012 & 0,71 & 3,59 & 1,01 & & & \\
\hline R013 & 0,75 & 3,57 & 0,98 & & & \\
\hline R014 & 0,67 & 3,37 & 1,03 & & & \\
\hline Zadovoljstvo z življenjem & & 16,30 & 4,13 & 0,85 & 0,88 & 0,86 \\
\hline $\mathrm{R} 015$ & 0,80 & 3,36 & 1,00 & & & \\
\hline R016 & 0,84 & 3,47 & 1,02 & & & \\
\hline R017 & 0,87 & 3,70 & 0,95 & & & \\
\hline R018 & 0,60 & 2,99 & 1,03 & & & \\
\hline R019 & 0,57 & 2,79 & 1,22 & & & \\
\hline Zadovoljstvo s samim seboj & & 10,92 & 2.38 & 0,82 & 0,72 & 0,82 \\
\hline R020 & 0,77 & 3,51 & 1,02 & & & \\
\hline R021 & 0,82 & 3,65 & 0,90 & & & \\
\hline R022 & 0,74 & 3,75 & 0,85 & & & \\
\hline \multicolumn{7}{|l|}{ Kovariance } \\
\hline & Empatija & Prosocialno & Žalost & Skrbi & Optimizem & Zad. z živ. \\
\hline Prosocialno & 0,25 & & & & & \\
\hline Žalost & $-0,02$ & 0,09 & & & & \\
\hline Skrbi & 0,19 & 0,07 & 0,52 & & & \\
\hline Optimizem & 0,23 & 0,07 & $-0,71$ & $-0,29$ & & \\
\hline Zadovoljstvo z življenjem & 0,18 & 0,04 & $-0,67$ & $-0,29$ & 0,78 & \\
\hline Zadovoljstvo s samim seboj & 0,19 & 0,08 & $-0,58$ & $-0,29$ & 0,74 & 0,78 \\
\hline
\end{tabular}

Opombe. $\alpha=$ Cronbachova $\alpha,(\mathrm{p})=$ izmerjena v predhodni raziskavi, $\omega=$ McDonaldov omega koeficient. 
Tabela 6. Zanesljivost dimenzije vprašalnika MDI: povezanost

\begin{tabular}{|c|c|c|c|c|c|c|}
\hline MDI: povezanost & Nasičenost & $M$ & $S D$ & $\alpha$ & $\alpha(p)$ & $\omega$ \\
\hline Šola & & 7,13 & 2,35 & 0,84 & 0,71 & 0,85 \\
\hline R023 & 0,80 & 2,19 & 0,90 & & & \\
\hline R024 & 0,87 & 2,39 & 0,89 & & & \\
\hline R025 & 0,76 & 2,56 & 0,89 & & & \\
\hline Doma & & 10,00 & 2,34 & 0,88 & 0,69 & 0,89 \\
\hline R026 & 0,82 & 3,45 & 0,78 & & & \\
\hline R027 & 0,91 & 3,34 & 0,86 & & & \\
\hline R028 & 0,81 & 3,20 & 0,96 & & & \\
\hline Soseščina & & 8,24 & 2,67 & 0,93 & 0,87 & 0,93 \\
\hline R029 & 0,89 & 2,68 & 0,97 & & & \\
\hline R030 & 0,93 & 2,78 & 0,93 & & & \\
\hline R031 & 0,89 & 2,78 & 0,93 & & & \\
\hline Vrstniki & & 11,78 & 2,30 & 0,82 & 0,79 & 0,82 \\
\hline $\mathrm{R} 032$ & 0,78 & 3,89 & 0,92 & & & \\
\hline R033 & 0,75 & 3,81 & 0,90 & & & \\
\hline R034 & 0,79 & 4,11 & 0,87 & & & \\
\hline Prijateljstvo & & 12,91 & 2,50 & 0,84 & 0,79 & 0,86 \\
\hline R035 & 0,88 & 4,49 & 0,84 & & & \\
\hline R036 & 0,88 & 4,29 & 1,01 & & & \\
\hline R037 & 0,68 & 4,13 & 1,01 & & & \\
\hline \multicolumn{7}{|l|}{ Kovariance } \\
\hline & Šola & Dom & Soseščina & Vrstniki & & \\
\hline Dom & 0,25 & & & & & \\
\hline Soseščina & 0,31 & 0,31 & & & & \\
\hline Vrstniki & 0,18 & 0,37 & 0,38 & & & \\
\hline Prijateljstvo & 0,15 & 0,29 & 0,31 & 0,59 & & \\
\hline
\end{tabular}

Opombe. $\alpha=$ Cronbachova $\alpha,(\mathrm{p})=$ izmerjena v predhodni raziskavi, $\omega=$ McDonaldov omega koeficient.

Tabela 7. Zanesljivost dimenzije vprašalnika MDI: šolske izkušnje

\begin{tabular}{|c|c|c|c|c|c|c|}
\hline MDI: šolske izkušnje & Nasičenost & $M$ & $S D$ & $\alpha$ & $\alpha(p)$ & $\omega$ \\
\hline Učna samoučinkovitost & & 11,18 & 2,34 & 0,75 & 0,79 & 0,76 \\
\hline R038 & 0,70 & 3,92 & 0,87 & & & \\
\hline R039 & 0,66 & 3,60 & 1,08 & & & \\
\hline R040 & 0,80 & 3,66 & 0,90 & & & \\
\hline Šolska klima & & 9.55 & 2,51 & 0,76 & 0,74 & 0,77 \\
\hline R051 & 0,69 & 3,28 & 1,03 & & & \\
\hline R052 & 0,83 & 3,08 & 0,99 & & & \\
\hline R053 & 0,65 & 3,20 & 1,03 & & & \\
\hline Viktimizacija & & 6,10 & 2,84 & 0,77 & 0,75 & 0,78 \\
\hline R062 & 0,64 & 1,30 & 0,76 & & & \\
\hline R063 & 0,78 & 1,89 & 1,34 & & & \\
\hline R064 & 0,70 & 1,68 & 1,02 & & & \\
\hline R065 & 0,59 & 1,25 & 0,72 & & & \\
\hline Pripadnost šoli & & 6,35 & 1,89 & & & \\
\hline \multicolumn{7}{|l|}{ Kovariance } \\
\hline & \multicolumn{2}{|c|}{ Samoučinkovitost } & \multicolumn{2}{|c|}{ Viktimizacija } & & \\
\hline Šolska klima & \multicolumn{2}{|c|}{0,34} & \multicolumn{2}{|c|}{$-0,19$} & & \\
\hline Viktimizacija & \multicolumn{2}{|c|}{$-0,15$} & & & & \\
\hline
\end{tabular}

Opombe. $\alpha=$ Cronbachova $\alpha,(p)=$ izmerjena v predhodni raziskavi, $\omega=$ McDonaldov omega koeficient. 
Tabela 8. Faktorska struktura dimenzij zavzetost in vztrajnost vprašalnika EPOCH

\begin{tabular}{lccccccrrr}
\hline Model & \multicolumn{2}{c}{ RMSEA [90 \% IZ] } & SRMR & NFI & TLI & CFI & $\chi^{2}$ & $d f$ & $p$ \\
\hline EPOCH & & & & & & & & \\
Model 1 & 0,20 & {$[0,19 ; 0,21]$} & 0,14 & 0,59 & 0,42 & 0,59 & 2592,35 & 20 & $<0,01$ \\
Model 2 & 0,10 & {$[0,09 ; 0,10]$} & 0,11 & 0,90 & 0,87 & 0,91 & 603,52 & 20 & $<0,01$ \\
Model 3 & 0,08 & {$[0,08 ; 0,09]$} & 0,06 & 0,93 & 0,90 & 0,93 & 433,74 & 19 & $<0,01$ \\
Model 4 & 0,04 & {$[0,03 ; 0,05]$} & 0,03 & 0,99 & 0,98 & 0,99 & 69,45 & 12 & $<0,01$ \\
\hline
\end{tabular}

Opombe: Model 1 = enofaktorski; Model $2=$ nekoreliran; Model $3=$ koreliran; Model $4=$ modificiran koreliran model.

Tabela 9. Mere zanesljivosti dimenzij zavzetost in vztrajnost

\begin{tabular}{|c|c|c|c|c|c|c|c|}
\hline \multirow[b]{2}{*}{ EPOCH: zavzetost in vztrajnost } & \multicolumn{2}{|c|}{ Nasičenosti } & \multirow[b]{2}{*}{$M$} & \multirow[b]{2}{*}{$S D$} & \multirow[b]{2}{*}{$\alpha$} & \multirow[b]{2}{*}{$\alpha(p)$} & \multirow[b]{2}{*}{$\omega$} \\
\hline & Model 3 & Model 5 & & & & & \\
\hline Zavzetost & & & 11,22 & 3,05 & 0,72 & 0,74 & 0,74 \\
\hline R004 & 0,66 & 0,65 & 3,08 & 1,05 & & & \\
\hline R005 & 0,78 & 0,80 & 2,97 & 1,00 & & & \\
\hline R006 & 0,72 & 0,71 & 2,56 & 1,08 & & & \\
\hline R009 & 0,38 & - & 2,58 & 0,98 & & & \\
\hline Vztrajnost & & & 13,04 & 3,27 & 0,75 & 0,80 & 0,76 \\
\hline R007 & 0,64 & 0,55 & 2,81 & 1,13 & & & \\
\hline R008 & 0,74 & 0,66 & 3,60 & 1,09 & & & \\
\hline R010 & 0,62 & 0,67 & 3,21 & 1,04 & & & \\
\hline R011 & 0,63 & 0,68 & 3,42 & 1,07 & & & \\
\hline Kovarianca & 0,30 & 0,27 & & & & & \\
\hline
\end{tabular}

Opombe. $\alpha=$ Cronbachova $\alpha,(p)=$ izmerjena v predhodni raziskavi, $\omega=$ McDonaldov omega koeficient.

kažejo celo večjo notranjo konsistentnost (glej SchonertReichl idr., 2013). Vsi koeficienti notranje skladnosti torej nakazujejo, da je vprašalnik na slovenskem vzorcu zanesljiv za uporabo rezultatov $\mathrm{v}$ raziskovalne namene.

\section{Vprašalnik EPOCH}

S konfirmatorno faktorsko analizo (tabela 8) sva preverjali ujemanje strukture dveh dimenzij s predvideno strukturo istih dveh dimenzij na vprašalniku v raziskavi Kerna in sodelavcev (2016). V raziskavo v Sloveniji sta bili vključeni dve dimenziji vprašalnika, to sta zavzetost in vztrajnost. Preverjali sva tako model, kjer je dopuščena vzajemna povezanost (model 3) med dimenzijama (latentnimi spremenljivkami), kot model brez vključitve vzajemne povezanosti (model 2). Rezultati v tabeli 8 kažejo, da se model 3 (model, kjer je upoštevana povezanost med dimenzijama) bolje ujema kot model 2 (brez medsebojne povezanosti med dimenzijama) in model 1 (enofaktorski model). Vse mere potrjujejo relativno zadostno (mejno) ujemanje. CFI znaša 0,93, čeprav je meja dobrega ujemanja CFI > 0,95 (Brown, 2006), enako velja za TLI. Rezultati mere RMSEA v modelu 3 so zadovoljivi (po Brownu, 2006, je dopustna meja RMSEA 0,08). Vse postavke razen postavke 9 so bile dobro nasičene $\mathrm{s}$ faktorji (tabela 9). Po pregledu kovarianc med ostanki sva zasledili, da se ostanek postavke 9 visoko povezuje z dimenzijo vztrajnosti. Model 4 je identičen modelu 3, s tem da sva iz analize izločili postavko 9. S tem so se izboljšale mere ujemanja (tabela 8). Rezultati potrjujejo dve medsebojno povezani dimenziji vprašalnika. Tudi Kern, Waters, Adler in White (2015), ki so koncept modela PERMA prvi preverjali pri mladostnikih, so potrdili večdimenzionalni konstrukt. Struktura vključenih dveh dimenzij iz EPOCH vprašalnika se sklada s strukturo, ki so jo ugotovili v omenjeni raziskavi.

Preverjali sva tudi mersko invariantnost po spolu. Iz tabele 10 je razvidno, da sta dimenziji na vprašalniku EPOCH skalarno invariantni po spolu, saj je sprememba indeksa CFI od konfiguralnega do metričnega modela in od metričnega do skalarnega modela manjša od 0,01 . Ne moreva potrditi stroge invariantnosti, saj je razlika v indeksu CFI pri skalarnem in strogem modelu večja od 0,01 . Indeksi prileganja (tabela 11) kažejo na dobro prileganje vseh modelov (od konfiguralnega do strogega).

Rezultati obeh dimenzij, zavzetost in vztrajnost, kažejo za uporabo v raziskovalne namene še sprejemljivo zanesljivost $(\alpha$ $>0,70, \omega>0,70$ ) (tabela 9). Hkrati pa so rezultati primerljivi z zanesljivostjo, izmerjeno v predhodni raziskavi (Kern idr., 2016). Zaključiva lahko, da je notranja skladnost pokazatelj ustrezne zanesljivosti obeh dimenzij za uporabo vprašalnika $\mathrm{v}$ raziskovalne namene na slovenskih vzorcih.

Tabela 10. Primerjava modelov za preverjanje merske invariantnosti glede na spol za vprašalnik EPOCH

\begin{tabular}{lcccc}
\hline Model & $\Delta \chi^{2}$ & $\Delta d f$ & $p$ & $\Delta$ CFI \\
\hline Metrični : konfiguralni & 17,57 & 6 & 0,007 & 0,002 \\
Skalarni : metrični & 20,67 & 3 & $<0,01$ & 0,003 \\
Strogi : skalarni & 76,11 & 8 & $<0,01$ & 0,011 \\
\hline
\end{tabular}


Tabela 11. Indeksi prileganja modelov merske invariantnosti glede na spol za vprašalnik EPOCH

\begin{tabular}{llllllll}
\hline Model & \multicolumn{2}{c}{ RMSEA } & NFI & TLI & CFI & $\chi^{2} / d f$ & $p$ \\
\hline Konfiguralni & 0,06 & {$[0,05 ; 0,06]$} & 0,93 & 0,90 & 0,93 & 12,25 & $<0,01$ \\
Metrični & 0,06 & {$[0,05 ; 0,06]$} & 0,93 & 0,91 & 0,93 & 10,98 & $<0,01$ \\
Skalarni & 0,06 & {$[0,05 ; 0,06]$} & 0,92 & 0,91 & 0,93 & 10,72 & $<0,01$ \\
Strogi & 0,05 & {$[0,05 ; 0,06]$} & 0,91 & 0,92 & 0,92 & 10,54 & $<0,01$ \\
\hline
\end{tabular}

Opombe. Vrednosti znotraj oglatih oklepajev pri RMSEA predstavljajo meje 90-odstotnega intervala zaupanja [spodnja meja, zgornja meja].

\section{Konvergentna in diskriminativna veljavnost}

Pri preverjanju konvergentne in diskriminativne veljavnosti obeh testov sva preverili povezanosti med dimenzijama vprašalnika EPOCH in podlestvicami vprašalnika MDI ter povezanost obeh z dimenzijami vprašalnika PYD (tabela 12). Konvergentna in diskriminativna veljavnost se vežeta na evalvacijo mer preko primerjave povezanosti med merami podobnih konstruktov, namesto primerjave $\mathrm{z}$ zunanjimi standardi. Konvergentno veljavnost preverjamo preko povezanosti mer oziroma dimenzij istega konstrukta, pri čemer morajo biti korelacije vsaj srednje moči ( $r$ je vsaj 0,24$)$; po drugi strani $\mathrm{z}$ diskriminativno veljavnostjo preverjamo raznolikost konstruktov, pri čemer povezanost ne sme biti prevelika ( $r$ je manj od 0,85) (Brown, 2006; Kline, 2011). Vsi vprašalniki merijo napovednike blagostanja, zato sva pričakovali povezanosti med večino dimenzij in podlestvic, ne pa med vsemi, saj so nekatere podlestvice po vsebini specifične (npr. nisva pričakovali povezanosti podlestvice skrb in vztrajnost). Dodatno so naju zanimale povezanosti s spolom, kar je bil najin drugi način za preverjanje konstruktne veljavnosti. Povezanost dosežka na vprašalniku EPOCH s spolom so preverjali tudi v prejšnji raziskavi (Kern idr., 2016), hkrati po so Schonert-Reichl idr. (2013) predlagali, da se v prihodnje validacije MDI vprašalnika vključi tudi razlike med spoloma.

\section{Konvergentna in diskriminativna veljavnost MDI}

Socialni in emocionalni razvoj. Optimizem, zadovoljstvo $\mathrm{z}$ življenjem in zadovoljstvo s samim seboj se statistično pomembno visoko povezujejo med seboj in višje kot $\mathrm{Z}$ ostalimi podlestvicami. Empatija in prosocialno vedenje se statistično pomembno pozitivno povezujeta med seboj in višje kot $\mathrm{z}$ ostalimi podlestvicami. Edina izjema sta povezanost empatije $\mathrm{z}$ zadovoljstvom $\mathrm{z}$ življenjem in $\mathrm{z}$ zadovoljstvom s samim seboj. Žalost in skrbi se statistično pomembno visoko pozitivno povezujeta med seboj. Podlestvica skrbi se z ostalimi konstrukti povezuje zelo blago. Po drugi strani pa se žalost statistično pomembno visoko negativno povezuje $\mathrm{s}$ podlestvicami zadovoljstvo $\mathrm{z}$ življenjem, samopodoba in optimizem (tabela 12). Smer povezav nakazuje ustrezno konstruktno veljavnost. Vse velikosti in smeri povezav se skladajo z ugotovitvami v raziskavi Schonert-Reichla idr. (2013). Velikost povezav med konstrukti ne presega predvidene višine povezanosti, kar nakazuje na dobro diskriminativno veljavnost.

Povezanost. Najvišje se povezujeta podlestvici, vezani na povezovanje mladostnikov $\mathrm{z}$ enako starimi, torej med vrstniki in prijatelji (tabela 12). Med seboj se povezujeta višje kot s podlestvicami povezanosti z odraslimi iz različnih okolij. Dosežki na podlestvici povezanost z odraslimi v šoli se najvišje povezujejo $\mathrm{z}$ dosežki na podlestvici povezanost $\mathrm{z}$ odraslimi v soseščini in dosežki na podlestvici povezanost $z$ odraslimi doma, manj močno pa se povezujejo $z$ dosežki na podlestvicah povezanost $\mathrm{z}$ vrstniki in prijateljstvo. Podlestvici povezanost $\mathrm{z}$ odraslimi doma in povezanost $\mathrm{z}$ odraslimi $\mathrm{v}$ soseščini se najvišje povezujeta $s$ podlestvico povezanost $\mathrm{z}$ vrstniki. Nekoliko manj se povezujeta med seboj in $\mathrm{s}$ podlestvico prijateljstva, kar je presenetljivo, saj se pojavlja višja povezava s skupino vrstnikov (za katere sklepava, da ne gre za tesne medosebne odnose) kot z ožjimi prijatelji in družinskimi vezmi (kjer po navadi gre za tesnejše medosebne odnose). Vse ostale povezanosti so skladne s predvidevanji na podlagi teorije (Schonert-Reichl idr., 2013), kar potrjuje dobro diskriminativno veljavnost.

Šolske izkušnje. Podlestvice učna samoučinkovitost, šolska klima in pripadnost šoli se statistično pomembno pozitivno povezujejo med seboj (tabela 12). Najvišje se povezujeta podlestvici šolska klima in pripadnost šoli. Viktimizacija se z vsemi tremi povezuje šibko in negativno, kar je skladno z ugotovitvami raziskave Schonert-Reichla idr. (2013). Moč povezanosti ne odstopa od pričakovanj, kar nakazuje na dobro diskriminativno veljavnost.

Zdravje. Splošno zdravje se statistično pomembno pozitivno povezuje s pogostostjo zajtrkovanja, pogostostjo prehranjevanja skupaj z družino, zadovoljstvom z videzom in negativno s spalnimi navadami. S telesno težo in s slabimi prehranjevalnimi navadami se ne povezuje statistično pomembno, vendar se kaže negativna povezava (tabela 12). Ugotovitve se skladajo z ugotovitvami Schonert-Reichla in sodelavcev (2013).

\section{Povezanost MDI z dimenzijami PYD}

Za preverjanje konstruktne veljavnosti vprašalnika MDI sva preverjali tudi povezanost tega vprašalnika z vprašalnikom PYD (tabela 12). Skladno s teorijo se dimenzija kompetentnost statistično pomembno povezuje s podlestvicami dimenzije šolske izkušnje: učna samoučinkovitost, šolska klima in pripadnost šoli. Kompetentnost vključuje tudi socialno področje, zato je pričakovana tudi povezanost $\mathrm{z}$ vsemi MDI podlestvicami dimenzije povezanost. Po predvidevanjih se dimenzija samozavest statistično pozitivno povezuje predvsem z MDI podlestvicami zadovoljstvo s samim seboj in $\mathrm{z}$ učno samoučinkovitostjo, hkrati pa tudi $\mathrm{z}$ optimizmom in zadovoljstvom $\mathrm{z}$ življenjem. PYD dimenzija skrb, kot je na podlagi teoretične definicije možno pričakovati, se pozitivno povezuje z MDI podlestvicami dimenzije socialni in emocionalni razvoj: empatija in prosocialno vedenje. 
Tabela 12. Pearsonovi korelacijski koeficienti med preučevanimi spremenljivkami

\begin{tabular}{|c|c|c|c|c|c|c|c|c|c|c|c|c|c|c|c|c|c|c|c|}
\hline & & 1 & 2 & 3 & 4 & 5 & 6 & 7 & 8 & 9 & 10 & 11 & 12 & 13 & 14 & 15 & 16 & 17 & 18 \\
\hline & $\mathrm{EPOCH}$ & & & & & & & & & & & & & & & & & & \\
\hline 1 & Zavzetost & & & & & & & & & & & & & & & & & & \\
\hline \multirow[t]{2}{*}{2} & Vztrajnost & ,26 & & & & & & & & & & & & & & & & & \\
\hline & MDI socialni in emocion & lni ra & $z v o j$ & & & & & & & & & & & & & & & & \\
\hline 3 & Optimizem & ,22 & ,29 & & & & & & & & & & & & & & & & \\
\hline 4 & Prosocialno vedenje &, 17 & ,12 & ,07 & & & & & & & & & & & & & & & \\
\hline 5 & Empatija &, 16 & ,20 & ,19 & ,24 & & & & & & & & & & & & & & \\
\hline 6 & Žalost &, 01 &,- 16 &,$- \mathbf{5 0}$ & ,09 &, 00 & & & & & & & & & & & & & \\
\hline 7 & Skrbi &, 02 & ,03 &,- 24 &, 07 & ,14 &, 50 & & & & & & & & & & & & \\
\hline 8 & Zadovoljstvo - življenje &, 19 & ,36 & ,63 &, 05 & ,17 &,- 50 &,- 26 & & & & & & & & & & & \\
\hline \multirow[t]{2}{*}{9} & Zadovoljstvo - s seboj & ,23 & ,36 &, 59 & ,07 & ,17 &,- 44 &,- 26 & ,67 & & & & & & & & & & \\
\hline & MDI povezanost & & & & & & & & & & & & & & & & & & \\
\hline 10 & Povezanost šola & ,18 & ,27 & ,23 & ,12 & ,19 &,- 09 &,- 01 & ,26 & ,28 & & & & & & & & & \\
\hline 11 & Povezanost dom &, 12 & ,26 & ,31 & 03 &, 23 &,- 25 &,- 06 & ,40 & ,35 & ,23 & & & & & & & & \\
\hline 12 & Povezanost soseščina & ,18 & ,21 & 28 & ,18 &, 23 &,- 16 &,- 08 & ,28 & ,31 & ,28 & ,28 & & & & & & & \\
\hline 13 & Povezanost vrstniki & ,13 & ,19 & ,42 &, 14 & ,26 &,- 33 &,- 19 & ,37 & ,40 &, 15 & ,32 &, 33 & & & & & & \\
\hline \multirow[t]{2}{*}{14} & Povezanost prijateljstvo & ,08 & ,10 & ,26 & ,21 & 32 &,- 14 &,- 03 & ,22 & ,22 &, 14 & ,26 & ,29 &, 51 & & & & & \\
\hline & MDI šolske izkušnje & & & & & & & & & & & & & & & & & & \\
\hline 15 & Učna samoučinkovitost & ,12 & ,47 & ,32 &, 05 & ,30 &,- 24 &,- 06 & ,39 & ,38 & ,28 & ,28 & ,19 & ,25 & ,16 & & & & \\
\hline 16 & Šolska klima &, 08 & ,23 & ,17 & 01 &, 22 &,- 08 & ,07 & ,23 & 21 & ,35 &, 17 & ,14 & ,17 & ,12 & ,29 & & & \\
\hline 17 & Pripadnost šoli & ,13 & ,32 & ,31 & ,08 & ,20 &,- 22 &,- 01 & ,36 & ,34 & ,40 & ,19 & ,18 & ,26 & ,16 & ,34 &, 55 & & \\
\hline \multirow[t]{10}{*}{18} & Viktimizacija & ,06 &,- 06 &,- 12 & ,22 &,- 12 & ,26 & ,20 &,- 15 & ,11 &, 02 &,- 14 &,- 03 &,- 20 &,- 13 &,- 12 &,- 16 &,- 09 & \\
\hline & $P Y D$ & & & & & & & & & & & & & & & & & & \\
\hline & Karakter & ,25 & ,33 & ,33 & ,24 &, 50 &,- 13 &,- 03 & ,34 & ,34 & ,25 & ,26 & ,24 & ,26 & ,23 & ,38 & ,27 & ,27 &,- 10 \\
\hline & Kompetence & ,21 & ,34 &, 47 & ,16 & ,11 &,- 38 &,- 25 & ,47 & ,47 &, 23 & ,26 & ,27 &, 49 & ,22 & ,33 & ,17 & ,33 &,- 11 \\
\hline & Zaupanje & ,21 & ,35 &, 55 & ,04 & ,17 &,- 40 &,- 28 & ,61 & ,61 & ,27 & ,36 & ,27 & ,40 & ,20 &, 44 & ,22 &, 37 &,- 15 \\
\hline & Skrb & ,20 & ,17 & ,14 & ,30 & ,62 & ,08 & -18 & ,11 & ,11 & ,18 & ,18 & ,20 & ,17 &, 25 & ,19 & ,19 &, 15 &,- 01 \\
\hline & Povezanost & ,18 & ,34 & ,43 &, 17 & ,30 &,- 34 &,-11 &, $\mathbf{5 0}$ &, 50 & ,39 &, 51 & ,39 &, 50 & ,40 & ,38 & ,35 &, 45 &,- 16 \\
\hline & Demografski podatki & & & & & & & & & & & & & & & & & & \\
\hline & Spol &,- 08 &,- 07 &,- 11 & ,08 & ,23 & ,18 & ,22 &,- 12 &,- 17 &,- 03 & ,02 &, 02 &,- 05 & ,17 & 03 & 03 &,- 05 &,- 08 \\
\hline & Starost &,- 02 &, 01 &,- 00 &,- 01 &,- 02 &, 00 &, 02 &, 01 &, 01 &,- 01 &,- 01 &,- 04 &,- 02 &,- 03 &, 01 &, 02 &, 01 &,- 03 \\
\hline
\end{tabular}

Opomba. Krepki tisk pomeni $p<.05$.

Hkrati se slednje statistično pomembno pozitivno povezuje z MDI podlestvicami dimenzije povezanosti. PYD dimenzija povezanost se $\mathrm{v}$ skladu $\mathrm{s}$ teorijo statistično pomembno povezuje $\mathrm{z}$ MDI podlestvicami dimenzije povezanost, $\mathrm{s}$ podlestvico pripadnost šoli, optimizmom in zadovoljstvom $\mathrm{z}$ življenjem. Smeri in velikosti povezanosti med omenjenimi dimenzijami in podlestvicami $z$ dimenzijami na vprašalniku PYD lahko razumemo kot dokaz konstruktne veljavnosti.

\section{Konvergentna in diskriminativna veljavnost $\mathrm{EPOCH}$}

Dimenziji zavzetost in vztrajnost se statistično pomembno pozitivno povezujeta med seboj (tabela 12), kar je nižje od povezanosti, ki jo v svoji raziskavi poročajo Kern in sodelvaci (2016), kjer $r$ znaša 0,46 . Hkrati pa je njuna povezanost manjša od mejne vrednosti za diskriminativno veljavnost $(r<$ 0,85) (Brown, 2006; Kline, 2011). Obe dimenziji vprašalnika se statistično pomembno povezujeta $\mathrm{z}$ vsemi dimenzijami vprašalnika PYD ( $r$ je med 0,18 in 0,35 ). Na podlagi podobnosti dimenzij je posebej pomembna povezanost dimenzij EPOCH (zavzetost: $r=0,21$, vztrajnost: $r=0,34$ ) z dimenzijo kompetentnosti, ki kaže na konvergentno veljavnost.

\section{Razlike med spoloma}

Iz tabele 12 je razvidno, da se pri vprašalniku MDI spol statistično pomembno povezuje $\mathrm{z}$ vsemi podlestvicami socialnega in emocionalnega razvoja, pri čemer je najšibkejša povezanost $s$ podlestvico prosocialno vedenje, najmočnejša pa s podlestvico empatija (tabela 12). Rezultati MANOVE potrjujejo statistično pomembno razliko med spoloma na vektorju dosežkov na podlestvicah socialnega in emocionalnega razvoja, $F(7,3214)=61,48, p<0,001$, Wilksova $\Lambda=.88, \eta^{2}=0,12$. Deklice dosegajo statistično pomembne višje rezultate na podlestvicah empatija $\left(M_{\text {ženske }}=\right.$ $12,60, S D_{\text {ženske }}=2,00, M_{\text {moški }}=11,56, S D_{\text {moški }}=2,44, F(1,3220)$ $=176,27, p<0,001)$, žalost $\left(M_{\text {ženske }}=8,40, S D_{\text {ženske }}=2,54\right.$, $\left.M_{\text {moški }}=7,51, S D_{\text {moški }}=2,45, F(1,3220)=103,40, p<0,001\right)$, $\operatorname{skrbi}\left(M_{\text {ženske }}=9,05, S D_{\text {žnnske }}=3,45, M_{\text {moški }}=7,52, S D_{\text {moški }}=3,23\right.$, $F(1,3220)=167,93, p<0,001)$ in prosocialno vedenje $\left(M_{\text {žnnske }}\right.$ $=8,06, S D_{\text {ženske }}=2,82, M_{\text {moški }}=7,55, S D=3,19, F(1,3220)$ $=22,81, p<0,001)$, dečki pa na podlestvicah zadovoljstvo $\mathrm{s}$ samim seboj $\left(M_{\text {ženske }}=10,52, S D_{\text {ženske }}=2,42, M_{\text {moški }}=11,33\right.$, $\left.S D_{\text {moški }}=2,27, F(1,3220)=96,64, p<0,001\right)$, zadovoljstvo $\mathrm{z}$ življenjem $\left(M_{\text {ženske }}=16,83, S D_{\text {ženske }}=4,11, M_{\text {moški }}=15,80\right.$, 
$\left.S D_{\text {moški }}=4,08, F(1,3220)=50,67, p<0,001\right)$ in optimizem $\left(M_{\text {ženske }}^{\text {moški }}=10,28, S D_{\text {ženske }}=2,42, M_{\text {moški }}=10,80, S D_{\text {moški }}=2,49\right.$, $F(1,3220)=36,15, p<0,001)$.

S spremenljivko spol se znotraj dimenzije povezanost statistično pomembno povezujeta le podlestvici povezanost z vrstniki in prijateljstvo (tabela 12). Rezultati MANOVE potrjujejo statistično pomembno razliko med spoloma, $F(5$, $3216)=38,36, p<0,001$, Wilksova $\Lambda=0,94, \eta^{2}=0,06$. Deklice poročajo o večji povezanosti z odraslimi v soseščini $\left(M_{\text {žnnke }}\right.$ $\left.=8,30, S D_{\text {žnense }}=2,79, M_{\text {moški }}=8,18, S D_{\text {moški }}=2,54\right)$, večji povezanosti z odraslim doma $\left(M_{\text {ženske }}=10,04, S D_{\text {ženske }}=2,39\right.$, $\left.M_{\text {moški }}=9,96, S D_{\text {moški }}=2,27\right)$ in pomembno višji povezanosti S prijatelji $\left(M_{\text {ženske }} \stackrel{\text { moški }}{=} 13,33, S D_{\text {ženske }}=2,31, M_{\text {moški }}=12,48\right.$, $\left.S D_{\text {moški }}=2,60, F(1,3220)=97,35, p<0,001\right)$. Dečki poročajo o večji povezanosti z odraslimi v šoli $\left(M_{\text {žnnse }}=7,08, S D_{\text {ženske }}\right.$ $\left.=2,34, M_{\text {moški }}=7,20, S D_{\text {moški }}=2,31\right)$ in $\mathrm{z}$ vrstniki $\left(M_{\text {žnnske }}=\right.$ $11,67, S D_{\text {ženske }}=2,28, M_{\text {moški }} \underset{\text { moški }}{=} 11,90, S D_{\text {moški }}=2,60, F(1,3220)$ $=8,00, p<0,05)$.

Znotraj dimenzije šolske izkušnje se statistično pomembno s spremenljivko spol povezujeta le podlestvici pripadnost šoli in viktimizacija (tabela 12). Rezultati MANOVE potrjujejo statistično pomembno razliko med spoloma, $F(3,3218)=9,25$, $p<0,001$, Wilksova $\Lambda=0,99, \eta^{2}=0,01$. Dečki poročajo o nekoliko višji šolski pripadnosti, $M_{\text {ženske }}=6,26, S D_{\text {ženske }}=$ $1,87, M_{\text {moški }}=6,45, S D_{\text {moški }}=1,91, F(1,3220)=7,92, p<0,05$. Na podlestvicah šolska samoučinkovitost in šolska klima se ne pojavljajo razlike med spoloma. $\mathrm{V}$ analizo nisva vključili podlestvice viktimizacije, saj dimenzija ne dosega pogojev merske invariantnosti po spolu.

Obe dimenziji vprašalnika EPOCH se statistično pomembno nizko negativno povezujeta s spremenljivko spol (tabela 12). MANOVA je pokazala statistično pomembne razlike med spoloma na obeh dimenzijah, $F(2,3219)=14,41$, $p<0,001$, Wilksova $\left.\Lambda=.99, \eta^{2}=0,01\right)$, pri čemer so tako na dimenziji zavzetost $\left(M_{\text {žnske }}=10,97, S D_{\text {ženske }}=3,00, M_{\text {moški }}\right.$ $\left.=11,47, S D_{\text {moški }}=3,09, F(1,3220)=21,98, p<0,001\right)$ kot vztrajnost $\left(M_{\text {ženske }}=12,83, S D_{\text {ženske }}=3,42, M_{\text {moški }}=13,26\right.$, $\left.S D_{\text {moški }}=3,11, F(1,3220)=13,88, p<0,001\right)$ fantje dosegali pomembno višje rezultate od deklet.

Smer razlik je skladna z ugotovitvami sorodnih raziskav. Pri interpretaciji najinih podatkov pa je treba biti previden, saj so koeficienti povezanosti med spolom in podlestvicami nizki ( $r$ je med 0,05 in 0,23 ) in hkrati je najin vzorec velik, kar lahko vpliva na statistično pomembnost koeficientov povezanosti. Na podlagi tega zaključujeva, da spol lahko igra vlogo pri blagostanju, vendar je povezanost nizka. Matthews, Kilgour, Christian, Mori in Hil (2015) so ugotovili razlike po spolu, na lestvici osebnega blagostanja (PWI-SC Personal Wellbeing Index; Cummins in Lau, 2005) dečki dosegajo statistično pomembno višje rezultate. V sklopu iste raziskave pa na lestvici splošne sreče (Happiness with Life - HLW; Cummins in Lau, 2005) niso ugotovili pomembnih razlik med spoloma. Razlike so ugotovili tudi na vprašalniku Kidscreen52 , kjer so deklice poročale nižjo stopnjo blagostanja kot dečki. Razlike so predvsem vidne na spremenljivkah telesno blagostanje in dojemanje sebe (samopodoba) (RavensSieberer idr., 2005). Kern in sodelavci (2016) poročajo o nepovezanosti vprašalnika EPOCH s starostjo, razredom ali spolom. Podobno tudi Opree s sodelavci (2018) ni ugotovil povezanosti blagostanja s spolom in starostjo.

\section{Zaključek}

V prispevku sva se osredinili na merske značilnosti dveh mer blagostanja, ki pred tem v Sloveniji še nista bili uporabljeni: vprašalnik MDI in dve dimenziji EPOCH. Preverjali sva tako zanesljivost (notranjo skladnost) kot veljavnost (konstruktno, diskriminantno in konvergentno) ter razlike med spoloma na velikem vzorcu slovenskih petnajstletnikov.

Ugotovili sva ustrezno zanesljivost obeh mer za uporabo $\mathrm{v}$ raziskovalne namene ter navedli dokaze konstruktne veljavnosti. Skladno s predpostavljeno strukturo ugotavljava, da dve izmed preverjenih dimenzij vprašalnika EPOCH tudi na slovenskem vzorcu petnajstletnikov kažejo podobno strukturo kot ti dimenziji v izvirnem vprašalniku. Vprašalnik EPOCH ima visoko praktično vrednost, saj se vrednosti na dimenzijah vprašalnika EPOCH, ugotovljene $\mathrm{v}$ predhodnih raziskavah (Kern idr., 2016), srednje močno in negativno povezujejo $\mathrm{z}$ merami čustvenega stresa in vedenjskimi težavami. Vse dimenzije se povezujejo tudi s telesnim zdravjem ter $\mathrm{z}$ manj poročanja o telesnih težavah. Posebej pomembna za področje vzgoje in izobraževanje je tudi pomembna povezanost $\mathrm{z}$ učno uspešnostjo. $\mathrm{Z}$ učno uspešnostjo (tudi po poročanju učiteljev) se najbolj povezuje dimenzija vztrajnost. Dimenzija zavzetost se najslabše povezuje $\mathrm{z}$ ostalimi konstrukti blagostanja, vendar se srednje močno povezuje z zadovoljstvom z življenjem, upanjem, pozitivnim afektom, šolsko zavzetostjo in smislom. Dimenziji vztrajnost in zavzetost sta pomembno povezani tudi na najinem vzorcu.

Strukturo, skladno z izvirnikom, ter ustrezno zanesljivost sva ugotovili tudi za mero MDI. Dodatna vrednost tako vprašalnika EPOCH kot MDI je njuna dimenzionalnost, ki nam omogoča bolj poglobljen vpogled v močna in šibka področja blagostanja posameznika. Na pomene vprašalnika EPOCH pri načrtovanju intervencij opozarjajo tudi Kern in sodelavci (2016). Žal sva lahko v raziskavi preverili samo dve od petih dimenzij vprašalnika EPOCH, zaradi česar je v prihodnjih raziskavah nujno preverjanje merskih značilnosti tudi preostalih treh dimenzij vprašalnika EPOCH. Večdimenzionalnost je priporočljiva tudi zato, ker so enodimenzionalne mere, kot je na primer samo zadovoljstvo z življenjem, močno pod vplivom posameznikovega razpoloženja v tistem času (Huppert in So, 2013).

Rezultati primerjave po spolu nam dajejo še dodatno praktično vrednost. Dekleta namreč poročajo o višji stopnji žalosti in skrbi ter na drugi strani o nižjem zadovoljstvu. To nakazuje, da je pri dekletih potrebno biti bolj pozoren na znake, ki bi nakazovali na povišanje negativnih emocij. Dečki po drugi strani poročajo o nižji stopnji empatije in prosocialnega vedenja. Tako bi bilo pri njih smiselno razmisliti o dodatnih intervencijah za razvijanje teh veščin.

Med pomembnejšimi omejitvami raziskave je zagotovo vključenost samo dveh dimenzij vprašalnika EPOCH. Podatki so sicer pridobljeni na velikem vzorcu petnajstletnikov, pa vendar bi bilo smiselno strukturo in merske značilnosti preveriti tudi na drugih starostnih skupinah ter hkrati ugotavljati razlike $\mathrm{v}$ blagostanju po starosti. Raziskave v tujini namreč kažejo pomemben učinek starosti (Ravens-Sieberer idr., 2005). Ne glede na omejitve pa lahko priporočava nadaljnjo uporabo mer predvsem $\mathrm{v}$ 
raziskovanju, medtem ko pri uporabi v praksi opozarjava na razmeroma nizko zansljivost (pod 0,80) nekaterih lestvic in $\mathrm{s}$ tem večjo previdnost pri interpretaciji.

\section{Literatura}

Antaramian, S. P., Huebner, E. S., Hills, K. J., in Valois, R. F. (2010). A dual-factor model of mental health: Toward a more comprehensive understanding of youth functioning. American Journal of Orthopsychiatry, 80(4), 462-472.

Avsec, A. in Kavčič, T. (2012). Merske značilnosti slovenske oblike Vprašalnika usmerjenosti k sreči (OTH). Psihološka obzorja, 21(1), 7-18.

Avsec, A. in Sočan, G. (2009). Validacija slovenske oblike Vprašalnika psihološkega blagostanja RPWB. Psihološka obzorja, 18(4), 4-19.

Bronfenbrenner, U. (1979). The ecology of human development. Harvard university press.

Brown, T. A. (2006). Confirmatory factor analysis for applied research. New York, NY, ZDA: Guilford Press.

Bullinger, M., Brütt, AL., Erhart, M., Ravens-Sieberer, U. in BELLA Study Group. (2008). Psychometric properties of the KINDL-R questionnaire: results of the BELLA study. European Child Adolescent Psychiatry, 17, 125-132.

Byrne, B. M. (2010). Structural equation modeling with AMOS: Basic concepts, applications, and programming. New York, NY, ZDA: Taylor \& Francis Group.

Cooke, P. J., Melchert, T. P. in Connor, K. (2016). Measuring well-being: A review of instruments. The Counseling Psychologist, 44(5), 730-757.

Csikszentmihalyi, M. (1997). Finding flow: The psychology of engagement with everyday life. Basic Books.

Csikszentmihalyi, M., \& Seligman, M. E. (2000). Positive psychology: An introduction. American Psychologist, 55(1), 5-14.

Cummins, R. A., in Lau, A. L. D. (2005). Personal WellBeing Index- School Children (PWI-SC) manual (3rd ed.). Melbourne, Australia: Deakin University.

Čufar, V., Kramaršek, P., Mahne, N. in Mohar, N. (2015). Vpliv pozitivnih intervencij na povečanje dobrega počutja. V Čufar, V., Kramaršek, P. in Mahne, N. (ur.), Raziskave študentov psihologije prve stopnje: Zbornik znanstvenoraziskovalnih prispevkov (str. 6-15). Maribor, Slovenija: Filozofska fakulteta.

Diener, E., Emmons, R, Larsen, R., \& Griffin, S. (1985). T he Satisfaction with Life Scale. Journal of Personality Assessment, 49, 1105-1117.

Eccles, J. S. (1999). The development of children ages 6 to 14. Future of Children, 9(2), 30-44.

Geldof, G. J., Bowers, E. P., Boyd, M. J., Mueller, M. K., Napolitano, C. M., Schmidt, K. L., ... Lerner, R. M. (2014). Creation of short and very short measures of the five C's of positive youth development. Journal of Research on Adolescence, 24(1), 163-176.

Greenberg, M. T., Weissberg, R. P., O’Brien, M. U., Zins, J. E., Fredericks, L., Resnik, H., \& Elias, M. J. (2003). Enhancing school-based prevention and youth development through coordinated social, emotional, and academic learning. American Psychologist, 58(6-7), 466-474.
Hills, P., \& Argyle, M. (2002). The Oxford Happiness Questionnaire: a compact scale for the measurement of psychological well-being. Personality and Individual Differences, 33(7), 1073-1082.

Huppert, F. A. in So, T. T. C. (2013). Flourishing across Europe: Application of a new conceptual framework for defining well-being. Social Indicators Research, 110(3), 837-861.

Kern, M. L., Benson, L., Steinberg, E. A. in Steinberg, L. (2016). The EPOCH measure of adolescent well-being. Psychological Assessment, 28(5), 586-597.

Kern, M. L., Waters, L. E., Adler, A. in White, M. A. (2015). A multidimensional approach to measuring well-being in students: Application of the PERMA framework. The Journal of Positive Psychology, 10(3), 262-271.

Kline, R. B. (2011). Principles and practice of structural equation modelling. New York, NY, ZDA: Guilford.

Kozina, A. in Štraus, M. (2017). Relationship between academic achievement as measured in the PISA study and wellbeing indicators: Preliminary findings. Šolsko polje, 28, 185-212.

Kozina, A., Wiium, N., Gonzalez, J. M. in Dimitrova, R. (2018). Positive youth development and academic achievement in Slovenia. Child \& Youth Care Forum, 1-18.

Lerner, R. M. (2007). The good teen: Rescuing adolescence from the myths of the storm and stress years. New York: Crown Publishing.

Lerner, R. M., von Eye, A., Lerner, J. V., \& Lewin-Bizan, S. (2009). Exploring the foundations and functions of adolescent thriving within the 4-H study of positive youth development: A view of the issues. Journal of Applied Developmental Psychology, 30(5), 567-570.

Masten, A. S. (2001). Ordinary magic: Resilience processes in development. American Psychologist, 56(3), 227-238.

Matthews, N., Kilgour, L., Christian, P., Mori, K. in Hil, D. M. (2015). Understanding, evidencing, and promoting adolescent well-being: An emerging agenda for schools. Youth \& Society, 47(5), 659-683.

Musek, J. (2015). Osebnost, vrednote in psihično blagostanje. Ljubljana, Slovenija: Znanstvena založba Filozofske fakultete Univerze v Ljubljani.

Ng, Z. J., Huebner, S. E., in Hills, K. J. (2015). Life satisfaction and academic performance in early adolescents: Evidence for reciprocal association. Journal of School Psychology, 53(6), 497-491.

OECD (2017). How's life? 2017: Measuring well-being. Pariz, Francija: Avtor. Pridobljeno s http://dx.doi. org/10.1787/how_life-2017-en

Opree, S. J., Buijzen, M. in Reijmersdal, E.A. (2018). Development and validation of the psychological wellbeing scale for children (PWB-C). Societies, 8(18), 1-14.

Peterson, C., Park, N., \& Seligman, M. E. (2005). Orientations to happiness and life satisfaction: The full life versus the empty life. Journal of Happiness Studies, 6(1), 25-41.

Phelps, E., Zimmerman, S., Warren, A.E.A., Jeličić, H., von Eye, A., in Lerner, R. M. (2009). The structure and developmental course of positive youth development (PYD) in early adolescence: Implications for theory and practice. Journal of Applied Developmental Psychology, 30(5), 571-584. 
Ravens-Sieberer, U., \& Bullinger, M. (1998). Assessing health-related quality of life in chronically ill children with the German KINDL: first psychometric and content analytical results. Quality of Life Research, 7(5), 399-407.

Ravens-Sieberer, U., Gosch, A., Rajmil, L., Erhart,M., Bruil,J., Duer,... Kidscreen Group E (2005). Kidscreen52 Quality of life measure for children and adolescents. Expert Review of Pharmacoeconomics \& Outcomes Research, 5(3), 353-365.

Ryan, R. M., \& Deci, E. L. (2000). Intrinsic and extrinsic motivations: Classic definitions and new directions. ContemporaryEducationalPsychology, 25(1), 54-67.

Ryff, C. D. (1989). Happiness is everything, or is it? Explorations on the meaning of psychological wellbeing. Journal of Personality and Social Psychology, 57(6), 1069-1081.

Schonert-Reichl, K.A., Guhn, M., Gadermann, A. M., Hymel, S., Sweiss, L. in Hertzman, C. (2013). Development and validation of the Middle Years Development Instrument (MDI): Assessing children's well-being and assets across multiple contexts. Social Indicators Research, 114(2), 345-369.

Seligman, M. E. P. (2011). Flourish. New York, NY, ZDA: Simon \& Schuster.

Smolej Fritz, B. in Avsec, A. (2007). The experience of flow and subjective well-being of music students, Psihološka obzorja, 16(2), 5-17.

Stevanovic, D. (2009). Serbian KINDL questionnaire for quality of life assessments in healthy children and adolescents: Reproducibility and construct validity. Health and Quality of Life Outcomes, 7(1), 1-7.

Strniša, J. (2007). Pomembnost in uresničenost vrednot v odnosu do subjektivnega blagostanja pri slovenskih in britanskih študentih. Psihološka obzorja, 16(2), 19-34.

The Children's Society (2017). The good childhood report 2017. Pridobljeno s https://www.childrenssociety.org. uk/what-we-do/resources-and-publications/the-goodchildhood-report-2017

Watson, D., Clark, L. A., \& Tellegen, A. (1988). Development and validation of brief measures of positive and negative affect: the PANAS scales. Journal of Personality and Social Psychology, 54(6), 1063-1070. 